\title{
Pengaruh Aplikasi Mikoriza dan Bahan Pembenah terhadap Sifat Kimia dan Serapan Fosfor di Tanah Pasir
}

\author{
Aktavia Herawati, Jauhari Syamsiyah, Mujiyo, Mapan Rochmadtulloh \\ Program Studi Ilmu Tanah, Fakultas Pertanian, Universitas Sebelas Maret \\ Jl. Ir. Sutami No. 36a Kentingan Surakarta \\ Korespondensi: aktavia_h@staff.uns.ac.id
}

\begin{abstract}
Sandy soil has limitations factor in supporting plant growth such as low soil organic carbon (SOC), cation exchange capacity (CEC), macro-micro nutrient content, water retention capacity, and high permeability rate. To improve soil conditions, it can be done by adding mycorrhizae and soil amendments. This study aimed to determine the effect of mycorrhizae application and soil amendments on the $P$ availability and $P$ uptake of plants in sandy soil. The research was conducted in a greenhouse of Agricultural Faculty, Sebelas Maret University. Used a completely randomized design consisting of 2 factors. The first factor was mycorrhizae with 2 levels, namely without mycorrhizae (M0) and mycorrhizae with 6 spores/plants (M1). The second factor was soil amendments; without amendment (P0), cow manure 60 tons/ha (P1), rock phosphate $150 \mathrm{~kg} / \mathrm{ha}$ (P2), and combination of cow manure 60 tons/ha and rock phosphate $150 \mathrm{~kg} / \mathrm{ha}(\mathrm{P3})$. The results showed that the application of mycorrhizae and soil amendments significantly increased available P, SOC, CEC, P concentration, and P uptake. Interaction of mycorrhizae 6 spores/plant and rock phosphate $150 \mathrm{~kg} / \mathrm{ha}$ was able to increase the availability of soil P up to 12.8 times, plant tissue $P$ concentration up to 1.4 times, and $P$ uptake up to 2.27 times compared to the control. Application of mycorrhizae 6 spores/plant and cow manure of 60 tons/ha gave the best results on SOC and mycorrhizae with a combination of cow manure and rock phosphate gave the best results on CEC.
\end{abstract}

Keywords: mycorrhizae, cow manure, rock phosphate, sandy soil.

\section{PENDAHULUAN}

Alih fungsi lahan dari pertanian ke non pertanian dari tahun ke tahun semakin meningkat. Menurut data (BPS, 2018) pada tahun 2017 luas sawah di Indonesia mengalami penurunan seluas 7,65 juta ha dan tahun 2018 seluas 7,1 juta ha. Penurunan luasan lahan ini bertolak belakang dengan peningkatan kebutuhan pangan. Salah satu strategi untuk memenuhi kebutuhan pangan adalah dengan memanfaatkan lahan-lahan sub-optimal diantaranya lahan pasir pantai.

Yogyakarta memiliki lahan pasir pantai seluas 13.000 hektar atau 4\% dari luas wilayah Yogyakarta secara keseluruhan, terbentang sepanjang $110 \mathrm{~km}$ di pantai Selatan lautan Indonesia. Bentangan pasir pantai ini berkisar antara 1-3 km dari garis pantai (Afif et. al., 2014). Namun, lahan pasir pantai memiliki kesuburan tanah yang rendah. Hal ini disebabkan oleh berbagai faktor pembatas yaitu sifat biofisik lahan dan sifat fisikokimia tanah pasir. Karakteristik biofisik yang tidak menguntungkan diantaranya suhu tanah pada siang hari sangat tinggi, evaporasi tinggi, angin kencang, kadar garam tinggi, serta bukit pasir yang mudah berubah (Kertonegoro, et. al., 2007). Karakteristik fisikokimia yang tidak menguntungkan diantaranya struktur tanah berbutir tunggal, persentase fraksi pasir $>90 \%$, konsistensi lepas sehingga menyebabkan permeabilitas sangat cepat, lengas tersedia dan kapasitas lapangan sangat rendah (Herawati, et. al., 2011) serta kemampuan menahan air (water holding capacity) sangat rendah yakni 1,6\% $3 \%$ dari total air yang tersedia. Rendahnya kemampuan menahan air mengakibatkan unsur hara mudah mengalami pelindian (leaching), kemampuan penjerapan kation rendah, dan kadar lengas tanah rendah, sehingga tanah pasir pantai miskin unsur hara akibatnya kesuburan tanahnya rendah (Weber et al., 2007).

Tanah pasir di pantai Bugel Kulonprogo mempunyai kadar C-organik sangat rendah, kadar $\mathrm{N}$ total rendah, $\mathrm{C} / \mathrm{N}$ rasio 4,5 , konsentrasi P-tersedia dan K-tersedia sedang, dan tidak tersedia bagi tanaman. Ca dan Mg tersedia sangat rendah dan konsentrasi $\mathrm{Na}$ sedang (Syukur et. al., 2010). Dengan meningkatknya kedalaman tanah, kadar bahan organik, kapasi- 
tas tukar kation, dan Sodium Adsorption Ratio (SAR) tanah cenderung menurun (Kertonegoro et. al., 2010).

Lahan pasir pantai dengan kandungan unsur hara yang rendah memerlukan masukan teknologi agar tercipta kondisi tanah yang mendukung untuk pertumbuhan baik tanaman pangan maupun tanaman hortikultura. Penggunaan mikoriza dan pembenah tanah merupakan salah satu strategi yang dapat dilakukan untuk memperbaiki karakteristik tanah pasir pantai. Aplikasi mikoriza ditujukan untuk melindungi tanaman dari cekaman kondisi fisik maupun kimia pada lahan pasir, memperluas jangkauan akar dalam menyerap unsur hara (Sosa-Hernández et. al., 2019) sehingga meningkatkan serapan hara fosfor yang tidak tersedia bagi tanaman.

Kebanyakan aplikasi mikoriza dilakukan pada lahan kering marginal masam seperti Ultisol (Nurhidayati et. al., 2010) maupun lahan yang terdegradasi akibat logam berat. Aplikasi dosis mikoriza dapat meningkatkan pertumbuhan tinggi tanaman 3 kali dari tanaman kontrol, memiliki berat kering tertinggi (Adetya et. al., 2018), serta meningkatkan penyerapan $\mathrm{P}$ dan unsur hara $\mathrm{N}, \mathrm{K}, \mathrm{S}, \mathrm{Ca}, \mathrm{Mg}, \mathrm{Cu}$ dan Zn (Li et. al., 2019). Hal ini disebabkan hubungan simbiosis mutualisme antara tanaman inang dengan hifa mikoriza sehingga jangkauan penyerapan akar meningkat dan membantu dalam penyerapan P.

Penggunaan bahan pembenah tanah diharapkan dapat memperbaiki sifat fisika, kimia, maupun biologi tanah pasir. Aplikasi pupuk kandang pada lahan pasir menunjukkan adanya peningkatan KTK tanah, konsentrasi kation basa, kandungan lengas, berat volume, dan kadar C-Organik tanah (Hasibuan, 2015). Penambahan unsur P dari Batuan Fosfat Alam (BFA) bertujuan untuk menghambat pelindian $\mathrm{P}$ pada tanah karena menyediakan unsur $\mathrm{P}$ yang lambat tersedia bagi tanaman (Maryanto \& Abubakar, 2010).

Berdasarkan hasil penelitian sebelumnya mikoriza dan pembenah tanah pupuk kandang serta BFA sangat tepat jika diaplikasikan di lahan pasir pantai. Hingga saat ini belum ada penelitian tentang mikoriza maupun kombinasi mikoriza dan pembenah tanah yang dilakukan untuk memperbaiki kesuburan tanah di lahan pasir pantai. Hal ini merupakan keterbaruan dari penelitian yang dilakukan. Penelitian ini bertujuan untuk mengetahui pengaruh kombinasi mikoriza dan berbagai pembenah tanah terhadap ketersedian $\mathrm{P}$ di dalam tanah dan serapan P pada tanaman cabai di tanah pasir pantai.

\section{BAHAN DAN METODE}

Penelitian dilaksanakan pada bulan MeiSeptember 2019 di Green House Kebun Percobaan Fakultas Pertanian Universitas Sebelas Maret. Rancangan percobaan disusun secara faktorial menggunakan Rancangan Acak Lengkap (RAL) faktorial yang terdiri dari dua faktor yaitu dosis mikoriza dan macam pembenah tanah. Faktor pertama dosis mikoriza terdiri atas 2 taraf yaitu: tanpa mikoriza (M0) dan mikoriza 6 spora/tanaman setara 10 gram mikoriza/tanaman (M1). Faktor kedua pembenah tanah terdiri dari 4 macam: tanpa pembenah (P0), pupuk kandang sapi 60 ton/ha (P1), Batuan Fosfat Alam (BFA) $150 \mathrm{~kg} / \mathrm{ha}$ (P2), dan pupuk kandang sapi 60 ton/ha + Batuan Fosfat Alam 150 kg/ha (P3). Masingmasing perlakuan dilakukan ulangan sebanyak 3 kali sehingga diperoleh 24 satuan percobaan.

Mikoriza yang digunakan merupakan pupuk hayati mikoriza dengan jenis endomikoriza dengan kandungan 30 spora dalam 50 gram carier zeolit (data primer), sehingga dalam 10 gram carier zeolit terdapat 6 spora mikoriza. Penentuan dosis 10 gram mikoriza /tanaman berdasarkan pada penelitian sebelumnya oleh Syamsiyah et. al., (2014), bahwa pada dosis mikoriza 5 gram/tanaman menunjukkan hasil terbaik pada padi. Pupuk kandang sapi yang digunakan memiliki $\mathrm{pH} \mathrm{H}_{2} \mathrm{O}$ 7,88; kadar C Organik 16,62\%, kadar N-total $0,63 \%$ dan $\mathrm{C} / \mathrm{N}$ ratio 26,39 . Sedangkan Batuan Fosfat Alam (BFA) yang digunakan memiliki pH $\mathrm{H}_{2} \mathrm{O}$ 7,91 dan kadar P-total 26,40\%.

Pasir yang digunakan diambil dari lahan pasir pantai Selatan di Kabupaten Bantul, tepatnya di sepanjang Pantai Samas. Sebelum digunakan, tanah pasir diayak dengan saringan 
diameter $2 \mathrm{~mm}$ lalu ditimbang seberat $10 \mathrm{~kg}$ per polibag. Bahan pembenah tanah dicampurkan sampai merata sesuai dengan perlakuan. Setelah itu diinkubasi selama 4 minggu. Inkubasi dilakukan dengan mempertahankan kondisi lengas tanah pada kapasitas lapang dengan periode pemberian air dua hari sekali.

Penanaman bibit cabai dilakukan bersamaan dengan aplikasi mikoriza. Spora mikoriza diletakkan tepat di bawah perakaran agar tanaman dapat terinfeksi oleh mikoriza. Pada saat tanaman berumur 14 HST diberi pupuk dasar berupa pupuk anorganik NPK 15-15-15 dengan dosis $100 \mathrm{~kg} / \mathrm{Ha}$ atau setara dengan $4 \mathrm{gr} / 10 \mathrm{~kg}$ dengan cara dibenamkan ke dalam tanah. Pemeliharaan tanaman meliputi penyiraman serta pengendalian gulma.

Setelah tanaman berumur 110 HST, dilakukan pengambilan sampel jaringan dengan cara memotong bagian trubus tanaman dan menyisakan akar. Akar yang masih tersisa pada polibag dikondisikan stressing dengan tidak dilakukan penyiraman selama 7 hari. Setelah itu dilakukan pengambilan sampel akar dan sampel tanah akhir untuk dianalisis di laboratorium.
Analisis sampel tanah meliputi $\mathrm{pH}$ tanah $\left(\mathrm{H}_{2} \mathrm{O}\right.$ 1:2,5) dengan metode potensiometri, $\mathrm{P}$ tersedia dengan metode Olsen, C-organik menggunakan metode Walkey dan Black, dan analisis kapasitas tukar kation (KTK) menggunakan metode penjenuhan Amonium Acetat $\mathrm{pH}$ 7,0. Sedangkan analisis tanaman meliputi kadar $\mathrm{P}$ jaringan (metode destruksi $\mathrm{HNO}_{3}$ dan $\mathrm{HClO}_{4}$ pekat) dan serapan P. Data yang diperoleh dianalisis dengan menggunakan Analysis of Varian (ANOVA) dengan taraf kepercayaan 95\%, kemudian dilakukan uji lanjut dengan Tukey HSD dengan taraf kepercayaan 95\%. Untuk mengetahui keterkaitan antar parameter dalam penelitian ini digunakan uji korelasi Pearson.

\section{HASIL DAN PEMBAHASAN}

\subsection{Karakteristik tanah awal dan bahan pembenah tanah}

Berdasarkan hasil analisis tanah pendahuluan diperoleh bahwa tanah pasir yang digunakan memiliki kadar $\mathrm{pH}_{2} \mathrm{O}$ netral, kadar $\mathrm{C}$ organik tanah, Nitrogen total dan kapasitas tukar kation sangat rendah, serta kandungan $P$ tersedia dan $\mathrm{K}$ tersedia rendah (Tabel 1).

Tabel 1 Karakteristik tanah pasir pantai

\begin{tabular}{lllll}
\hline No & Parameter & Metode & Nilai & Kriteria \\
\hline 1. & pH $\mathrm{H}_{2} \mathrm{O}$ & Potensiometri & 7,12 & Netral \\
2. & C-Organik (\%) & Walkey and Black & 0,18 & Sangat rendah \\
3. & N total (\%) & Kjeldahl & 0,015 & Sangat rendah \\
4. & C/N Rasio & Rasio C dan N tanah & 14,34 & Sedang \\
5. & P tersedia (ppm) & Olsen & 7,34 & Rendah \\
6. & K tersedia (ppm) & Penjenuhan NH40Ac 1 N & 0,27 & Rendah \\
7. & KTK (cmol/kg) & Penjenuhan NH4OAc 1 N & 4,43 & Sangat rendah \\
8. & Kepadatan spora/50 gram & Penyaringan Basah & tt & - \\
9. & Tekstur: & Pemipetan & Pasir \\
& Pasir & & $92,23 \%$ & \\
& Debu & & $6,81 \%$ & \\
& Lempung & & $0,96 \%$ & \\
\hline
\end{tabular}

Reaksi $(\mathrm{pH})$ tanah pada tanah pasir pantai tergolong netral disebabkan karena adanya akumulasi garam. Secara keseluruhan tanah yang digunakan memiliki tingkat kesuburan yang rendah. Rendahnya kesuburan tanah sangat berkaitan erat dengan sifat biofisik lahan dan sifat tanah yaitu tekstur tanah yang didominasi oleh fraksi pasir dan kandungan C organik yang sangat rendah. Tanah dengan tekstur pasir memiliki agregasi yang rendah sehingga kurang dapat menyimpan air karena memiliki permeabilitas tanah yang sangat cepat. Semakin kasar tekstur, maka bidang jerapan tanah semakin sedikit sehingga unsur 
hara dan air tidak bisa diikat oleh tanah karena mengalami pelindian (leaching). Hal ini dibuktikan dengan nilai KTK yang sangat rendah $(4,43 \mathrm{cmol} / \mathrm{kg}), \mathrm{N}$-total sangat rendah $(0,015 \%)$, P-tersedia rendah (7,34 ppm) dan K tersedia rendah $(0,27 \mathrm{ppm})$. Sumber muatan KTK pada tanah ditentukan oleh kandungan bahan organik, kadar liat (tekstur), dan tipe liat (Mengel, 1993). Idealnya kandungan bahan organik pada tanah mineral sebesar $5 \%$. Bahan organik juga menjadi salah satu sumber unsur hara dalam tanah. Hal tersebut tentu akan berdampak dalam produktivitas tanaman pada lahan pasir.

Bahan pembenah yang digunakan dalam penelitian telah memenuhi persyaratan bahan pembenah tanah berdasarkan Permentan 2011 yaitu C/N rasio (25-35\%) dan pH (4-9). Kandungan P total dalam BFA sebesar $26,40 \%$ juga memenuhi baku mutu SNI 02-3776-2005 dan tergolong mutu B ( $\min 24 \%$ ). Hasil analisis bahan pembenah yang digunakan dapat dilihat pada Tabel 2.

Tabel 2 Karakteristik bahan pembenah tanah

\begin{tabular}{lllrr}
\hline No & Parameter & Satuan & $\begin{array}{c}\text { Pupuk } \\
\text { kandang }\end{array}$ & BFA \\
\hline 1. & pH & - & 7,88 & 7,91 \\
2. & C-Organik & $\%$ & 16,62 & - \\
3. & N total & $\%$ & 0,63 & - \\
4. & C/N Rasio & - & 26,39 & - \\
5. & P total & $\%$ & - & 26,40 \\
\hline
\end{tabular}

Bahan pembenah yang digunakan dalam penelitian telah memenuhi persyaratan bahan pembenah tanah berdasarkan Permentan 2011 yaitu C/N rasio (25-35\%) dan pH (4-9). Kandungan P total dalam BFA sebesar $26,40 \%$ juga memenuhi baku mutu SNI 02-3776-2005 dan tergolong mutu B ( $\min 24 \%$ ).

\subsection{Pengaruh aplikasi mikoriza, pupuk kandang dan BFA terhadap sifat kimia tanah}

Tabel 3 menunjukkan bahwa interaksi mikoriza (M) dan bahan pembenah tanah berupa pupuk kandang dan batuan fosfat alam (P) berpengaruh sangat nyata terhadap $P$ tersedia tanah, $\mathrm{C}$ organik, dan kapasitas tukar kation tanah. Interaksi mikoriza dan bahan pembenah tanah tidak berpengaruh nyata terhadap $\mathrm{pH}$ tanah. Nilai $\mathrm{pH}$ pada seluruh perlakuan kombinasi mikoriza dan bahan pembenah termasuk dalam harkat netral. Sehingga $\mathrm{pH}$ tanah bukan sebagai faktor pembatas dalam pertumbuhan tanaman. Dariah et. al., (2015) menyebutkan bahwa penambahan pembenah tanah pada tanah pasir bertujuan sebagai buffer (penyangga).

Tabel 3 Hasil Uji ANOVA pada karakteristik kimia tanah

\begin{tabular}{|c|c|c|c|c|}
\hline Parameter & $\mathrm{pH}$ & $\begin{array}{c}\mathrm{P}- \\
\text { tersedia }\end{array}$ & $\begin{array}{c}\mathrm{C}- \\
\text { Organik }\end{array}$ & KTK \\
\hline M & $0,958^{\mathrm{n}}$ & $0.007^{* *}$ & $0,867 \mathrm{~ns}$ & $0,000^{* *}$ \\
\hline $\mathrm{P}$ & $0,932^{\mathrm{n}}$ & $0.008^{* *}$ & $0,000^{* *}$ & $0,000^{* *}$ \\
\hline$M \times P$ & $0,824^{n}$ & $0.004^{* *}$ & $0,001^{* *}$ & $0,000^{* *}$ \\
\hline
\end{tabular}

Pada perlakuan mikoriza dan BFA (M1P2) menunjukkan nilai $P$ tersedia $115,17 \mathrm{ppm}$ atau meningkat 12,8 kali dari perlakuan kontrol (Tabel 4). BFA merupakan salah satu sumber unsur Pyang relatif lambat menyediakan unsur $\mathrm{P}$ bagi tanaman. Karena kelarutannya yang rendah, BFA harus diaplikasikan bersamaan dengan organisme pelarut fosfat untuk mempercepat ketersediaan $\mathrm{P}$ dalam tanah (Simfukwe \& Tindwa, 2018).

Tabel 4 Pengaruh interaksi mikoriza dan pembenah tanah terhadap P tersedia tanah (ppm)

\begin{tabular}{ccccc}
\hline & P0 & P1 & P2 & P3 \\
\hline \multirow{2}{*}{ M0 } & $9,99 a$ & $30,01 a$ & $25,25 a$ & $55,26 a$ \\
& B & A & B & A \\
M1 & $21,01 b$ & $77,47 a b$ & $115,17 a$ & $27,33 b$ \\
& A & A & A & A \\
\hline
\end{tabular}

Keterangan: Angka rata-rata yang diikuti oleh notasi huruf yang sama tidak berbeda nyata berdasarkan hasil uji lanjut Tukey pada taraf 95\%. Notasi huruf kecil dibaca ke arah horizontal, notasi huruf besar dibaca ke arah vertikal.

Inokulasi mikoriza dapat meningkatkan ketersediaan unsur hara makro seperti P yang berada dalam bentuk tidak tersedia di dalam tanah. Kombinasi mikoriza dan BFA akan mempercepat kelarutan $\mathrm{P}$ melalui asam organik yang dihasilkan. Inokulasi mikoriza 
bersamaan dengan aplikasi BFA dapat meningkatkan P tersedia tanah (Azcon et al., 1976; Li et al., 2019). Menurut Johnson, et. al., (2016) mikoriza mempunyai peran yang penting terhadap hara tanaman dengan mengakses hara yang tidak tersedia bagi tanaman dari sumber anorganik maupun organik.

Uji ANOVA menunjukkan bahwa terdapat interaksi sangat nyata antara mikoriza dan pembenah $\left(p=0,001^{* *}\right)$ terhadap kandungan $C$ Organik tanah (Tabel. 3). Pupuk kandang berasal dari sisa-sisa makhluk hidup yang mengandung unsur karbon. Sehingga dengan menambahkan bahan yang mengandung karbon, jumlah karbon organik dalam tanah pun akan meningkat. Hasil Uji Tukey (5\%) menunjukkan kandungan $\mathrm{C}$ organik tertinggi terdapat pada perlakuan kombinasi mikoriza dan pupuk kandang (M1P1) sebesar 0,57\%. meningkat 3,3 kali dari perlakuan kontrol (Tabel 5). Hal ini menunjukkan bahwa aplikasi mikoriza 6 spora/tanaman dan pembenah pupuk kandang sapi dapat meningkatkan $\mathrm{C}$ organik pada tanah pasir.

Tabel 5 Pengaruh interaksi mikoriza dan pembenah tanah terhadap C organik (\%)

\begin{tabular}{ccccc}
\hline & P0 & P1 & P2 & P3 \\
\hline \multirow{2}{*}{ M0 } & $0,17 \mathrm{bc}$ & $0,32 \mathrm{ab}$ & $0,11 \mathrm{c}$ & $0,45 \mathrm{a}$ \\
& $\mathrm{A}$ & $\mathrm{A}$ & $\mathrm{A}$ & A \\
M1 & $0,12 \mathrm{~b}$ & $0,57 \mathrm{a}$ & $0,07 \mathrm{~b}$ & $0,27 \mathrm{~b}$ \\
& $\mathrm{~B}$ & $\mathrm{~A}$ & $\mathrm{~A}$ & $\mathrm{~B}$ \\
\hline
\end{tabular}

Keterangan: Angka rata-rata yang diikuti oleh notasi huruf yang sama tidak berbeda nyata berdasarkan hasil uji lanjut Tukey pada taraf 95\%. Notasi huruf kecil dibaca ke arah horizontal, notasi huruf besar dibaca ke arah vertikal.

Mikoriza melalui akar eksternalnya akan menghasilkan senyawa berupa glikoprotein glomalin dan asam-asam organik yang dapat meningkatkan kadar C-organik tanah. Sejalan dengan Singh et. al., (2013) bahwa karbon dalam glomalin memiliki kontribusi yang besar terhadap peningkatan C-organik tanah dan berdampak pada perbaikan tanah. Alvernia, et. al., (2017) menyebutkan bahwa penambahan pupuk kandang 5 ton/ha pada tanah Alfisol dapat meningkatkan C-organik sebesar 26\% dari perlakuan kontrol. Hasil penelitian Barus et. al., (2013) menunjukkan bahwa pemberian pupuk kandang dengan takaran 40 ton/ha dan 80 ton/ha pupuk kandang menghasilkan laju pertumbuhan tanaman tertinggi pada kedelai di tanah pasir. Głąb et al., (2020) juga mengatakan bahwa kandungan C organik ataupun bahan organik dapat ditingkatkan melalui penambahan amandemen organik seperti kompos yang berfungsi untuk memperbaiki sifat tanah maupun sebagai penyedia nutrisi tanaman.

Interaksi mikoriza dengan pembenah tanah memberikan pengaruh yang sangat signifikan $\left(\mathrm{p}=0,000^{* *}\right)$ terhadap KTK tanah (Tabel. 3). Hasil uji Tukey (5\%) menunjukkan bahwa interaksi mikoriza dengan pupuk kandang dan BFA mempunyai nilai KTK tertinggi $(12,99 \mathrm{cmol} / \mathrm{kg})$, atau mampu meningkat 2,8 kali dari perlakuan kontrol (Tabel 6).

Tabel 6 Pengaruh interaksi mikoriza dan pembenah tanah terhadap KTK (cmol/kg)

\begin{tabular}{ccccc}
\hline & P0 & P1 & P2 & P3 \\
\hline \multirow{2}{*}{ M0 } & $4,57 b$ & $6,58 b$ & $9,5 a$ & $6,74 b$ \\
& B & A & A & B \\
M1 & $7,31 b$ & $8,65 b$ & $6,08 b$ & $12,99 a$ \\
& A & A & B & A \\
\hline
\end{tabular}

Keterangan: Angka rata-rata yang diikuti oleh notasi huruf yang sama tidak berbeda nyata berdasarkan hasil uji lanjut Tukey pada taraf 95\%. Notasi huruf kecil dibaca ke arah horizontal, notasi huruf besar dibaca ke arah vertikal.

Aplikasi mikoriza dapat meningkatkan KTK tanah. Menurut Syib'li et al., (2013) mikoriza memiliki interaksi yang tinggi dengan karbon organik, bahan organik, fosfor total, dan kapasitas tukar kation. Pupuk kandang mengandung komponen karbon organik yang mengandung gugus hidroksil, karboksil, dan fenolik yang bermuatan negatif. Oleh sebab itu, aplikasi pupuk kandang dapat memberikan pengaruh yang signifikan pada KTK tanah (Haliru et. al., 2015). Unsur hara tanah menjadi tidak mudah tercuci karena KTK dan kandungan bahan organik yang tinggi (Bruun 
et. al., 2012). Kombinasi antara pembenah pupuk kandang dan BFA memberikan kontribusi terhadap kenaikan kation basa yang ada di dalam tanah. Pada saat proses dekomposisi, akan terjadi pelepasan unsur hara yang diantaranya terdiri dari kationkation basa (Cai et. al., 2019). Selain kandungan unsur $\mathrm{P}$, pada BFA juga terkandung unsur $\mathrm{Ca}$ dan Mg (Kasno \& Sutriadi, 2012). Saat pelepaskan unsur $\mathrm{P}$, unsur Ca dan Mg pun ikut terlepas dari BFA (Caravaca et. al., 2004). Semakin tinggi KTK maka semakin tinggi juga kemampuan tanah dalam menyimpan unsur hara, sehingga dengan meningkatnya KTK pertumbuhan tanaman juga akan meningkat (Sithole \& Magwaza, 2019).

Faktor yang mempengaruhi aktivitas mikoriza antara lain bahan organik, aerasi, $\mathrm{pH}$ dan ketersediaan hara. Mikoriza akan mudah berkembang pada tanah yang beraerasi baik seperti tanah pasiran. Semakin stress kondisi lingkungan, maka kinerja mikoriza akan semakin tinggi. Semakin terbatas jumlah hara yang tersedia, peluang mikoriza untuk menginfeksi tanaman juga akan lebih tinggi (Astiko et al.,, 2013). Hal yang sama juga dikemukakan oleh Sosa-Hernández et. al., (2019) bahwa mikoriza dapat memberikan akses nutrisi dan air pada kondisi tanah yang suboptimal. Rendahnya kadar P tersedia dapat mempengaruhi aktivitas mikoriza dalam tanah, akibatnya inokulasi mikoriza dapat mempercepat kolonisasi mikoriza pada akar tanaman di tanah dengan kondisi $P$ tersedia yang rendah (Hu et. al., 2009).

Hasil penelitian Syamsiyah et. al., (2014) menunjukkan bahwa perlakuan mikoriza mampu meningkatkan glomalin mudah diekstrak (easily extractable glomalin-related soil protein) sebanyak 20\%. Menurut Xie et. al., (2015) pemberian pupuk kandang dapat meningkatkan glomalin mudah diekstrak dan glomalin total karena adanya pelepasan zat pemacu pertumbuhan akibat meningkatnya nutrisi untuk aktivitas biologis tanah dari pupuk kandang. Rillig (2004) menyatakan bahwa glomalin akan terlepas dari hifa kemudian menyatu dengan tanah dan bahan organik untuk membuat agregat. Dengan adanya glomalin tersebut menyebabkan peningkatan agregat di tanah pasir (Syamsiyah et. al., 2018) sehingga akan meningkatkan kemampuan tanah untuk menahan dan menyimpan air serta unsur hara. Peningkatan agregasi tanah akan berpengaruh terhadap kapasitas tukar kation tanah. GRSP atau Glomalin Related Soil Protein bersama-sama dengan karbon dan nitrogen organik yang ada di dalam tanah menjadi sumber hara tersedia bagi tanaman yang sangat penting bagi siklus hara dan ekosistem (Treseder \& Turner, 2007).

\subsection{Pengaruh aplikasi mikoriza, pupuk kandang dan BFA terhadap serapan $P$ tanaman}

Hasil uji ANOVA menunjukkan terdapat pengaruh yang sangat nyata $(\mathrm{p}=0,000)$ pada perlakuan kombinasi mikoriza dan bahan pembenah terhadap kadar $\mathrm{P}$ jaringan tanaman (Tabel 7).

Tabel 7. Hasil ANOVA

\begin{tabular}{lrc}
\hline Parameter & P Jaringan & Serapan P \\
\hline $\mathrm{M}$ & $0,000^{* *}$ & $0,000^{* *}$ \\
$\mathrm{P}$ & $0,000^{* *}$ & $0,016^{*}$ \\
$\mathrm{M} \mathrm{x} \mathrm{P}$ & $0,000^{* *}$ & $0,019^{*}$ \\
\hline Keterangan: & $\begin{array}{l}\text { *berpengaruh nyata, } \\
\text { sa } \\
\text { sangat nyata, ns: tidak berpengaruh } \\
\text { nyata }\end{array}$ &
\end{tabular}

Kadar P jaringan tertinggi terdapat pada perlakuan mikoriza 6 spora/tanaman dan batuan fosfat alam $150 \mathrm{~kg} / \mathrm{ha}$ M1P2 $(0,40 \%)$ yang menunjukkan peningkatan 1,4 kali dibanding perlakuan kontrol (Tabel 8).

Tabel 8 Pengaruh interaksi mikoriza dan pembenah tanah terhadap $\mathrm{P}$ jaringan $(\%)$

\begin{tabular}{ccccc}
\hline & P0 & P1 & P2 & P3 \\
\hline \multirow{2}{*}{ M0 } & $0,29 a$ & $0,2 c$ & $0,25 b$ & $0,27 a b$ \\
& A & A & B & A \\
M1 & $0,27 b$ & $0,29 b$ & $0,4 a$ & $0,28 b$ \\
& B & B & A & A \\
\hline
\end{tabular}

Keterangan: Angka rata-rata yang diikuti oleh notasi huruf yang sama tidak berbeda nyata berdasarkan hasil uji lanjut Tukey pada taraf 95\%. Notasi huruf kecil dibaca ke arah horizontal, notasi huruf besar dibaca ke arah vertikal. 
Hifa mikoriza akan mengalami perpanjangan sehingga dapat menyerap P yang tidak dapat terjangkau oleh akar. Hal ini sesuai dengan (Smith et. al., 2011) bahwa penyerapan $P$ oleh mikoriza diikuti juga dengan peningkatan $\mathrm{P}$ jaringan pada tanaman inangnya sehingga aplikasi mikoriza dan pembenah tanah dapat meningkatkan $P$ jaringan tanaman dibandingkan perlakuan kontrol (WattsWilliams et. al., 2014).

Inokulasi mikoriza bersamaan dengan aplikasi BFA dapat meningkatkan $\mathrm{P}$ tersedia tanah. Peningkatan konsentrasi $\mathrm{P}$ jaringan tanaman akan berpengaruh terhadap serapan $\mathrm{P}$ tanaman. Hal ini selaras dengan hasil Uji Tukey (5\%) yang menunjukkan bahwa serapan $\mathrm{P}$ tertinggi terdapat pada perlakuan M1P2 (31,25 mg/tanaman), meningkat 2,27 kali dibanding kontrol (Tabel 9). Interaksi mikoriza dan BFA mampu meningkatkan serapan fosfor pada tanaman. Hifa mikoriza dapat memperluas jangkauan perakaran sehingga serapan hara pada tanaman menjadi lebih tinggi. Terdapat korelasi positif antara $P$ total jaringan dengan serapan $P\left(R^{2}=0,687\right)$ (Tabel 10).

Tabel 9 Pengaruh interaksi mikoriza dan pembenah tanah terhadap Serapan $\mathrm{P}(\mathrm{mg} /$ tanaman $)$

\begin{tabular}{ccccc}
\hline & P0 & P1 & P2 & P3 \\
\hline \multirow{2}{*}{ M0 } & $13,79 a$ & $11,15 a$ & $13,33 a$ & $7,96 a$ \\
& B & B & B & B \\
M1 & $22,21 b$ & $26,59 a b$ & $31,25 a$ & $25,95 a b$ \\
& A & A & A & A \\
\hline \multirow{2}{*}{ Keterangan: Angka rata-rata yang diikuti } & oleh notasi \\
& huruf yang sama tidak berbeda nyata & berdasarkan hasil uji lanjut Tukey pada \\
& taraf 95\%. Notasi huruf kecil dibaca ke \\
& arah horizontal, notasi huruf besar dibaca \\
& ke arah vertikal.
\end{tabular}

Menurut Syamsiyah et. al., (2014), tanaman yang terinfeksi oleh mikoriza akan mengalami peningkatan serapan unsur $P$ sebanyak 3\% dan $\mathrm{N}$ sebanyak 5\%. Hal tersebut disebabkan karena mikoriza mendorong berkembangnya hifa yang ada pada akar tanaman inang sehingga meningkatkan proses penyerapan unsur hara. Selain itu akar yang terinfeksi oleh mikoriza akan semakin meningkatkan daya jelajah karena adanya hifa eksternal yang berada di luar akar, sehingga tanaman mampu bertahan dalam cekaman air dan hara yang minimum.

Tabel 10 Korelasi positif antar parameter

\begin{tabular}{lll}
\hline Parameter & P tersedia & Serapan $P$ \\
\hline P jaringan & 0,650 & 0,687 \\
Serapan P & 0,477 & - \\
\hline
\end{tabular}

Ortas and Ustuner (2014) menyatakan bahwa kolonisasi mikoriza pada akar tanaman dapat meningkatkan pertumbuhan akar, seperti berat, panjang, maupun diameter akar. Tanaman yang akarnya terinfeksi oleh mikoriza akan mempunyai volume permukaan akar yang besar, sehingga mampu menyerap unsur hara lebih banyak (Smith \& Read, 2008). Tanaman yang terinfeksi mikoriza akan tumbuh lebih subur karena luas permukaan akar yang lebih besar dalam menyerap hara dan jumlah daun lebih banyak untuk mendukung proses fotosintesis sehingga menghasilkan lebih banyak biomassa tanaman. Sejalan dengan Kasno \& Sutriadi, (2012) dan Masruroh et. al.,, (2019) bahwa pemberian unsur $P$ dengan BFA dapat meningkatkan produktivitas pada tanaman.

\section{KESIMPULAN}

Interaksi mikoriza 6 spora/tanaman dan BFA $150 \mathrm{~kg} / \mathrm{ha}$ mampu meningkatkan $\mathrm{P}$ tersedia tanah 12,8 kali, konsentrasi $\mathrm{P}$ jaringan tanaman 1,4 kali serta serapan P tanaman 2,27 kali dibanding kontrol. Perlakuan mikoriza 6 spora/tanaman dan pupuk kandang sapi 60 ton/ha memberikan hasil terbaik terhadap $\mathrm{C}$ organik tanah dan perlakuan mikoriza dengan kombinasi pupuk kandang dan BFA memberikan hasil terbaik pada KTK tanah. Perlakuan mikoriza 6 spora/tanaman dan pembenah tanah secara nyata mampu meningkatkan C organik, kapasitas tukar kation dan ketersedian unsur hara $\mathrm{P}$ di tanah pasir serta serapan $P$ jaringan tanaman. Dengan demikian kombinasi mikoriza dan bahan pembenah tanah berupa batuan fosfat alam berpotensi sebagai bahan untuk meningkatkan ketersedian fosfor di tanah pasir dan konsentrasi $\mathrm{P}$ di dalam jaringan 
tanaman serta serapan $\mathrm{P}$ tanaman di tanah pasir pantai.

\section{DAFTAR PUSTAKA}

Adetya, V., Nurhatika, S., \& Muhibuddin, A. 2018. Pengaruh pupuk mikoriza terhadap pertumbuhan cabai rawit (Capsicum frutescens) di tanah pasir. Jurnal Sains dan Seni ITS. 7(2): E75E79.

Afif, T., Kastono, D., \& Yudono, P. 2014. Pengaruh macam pupuk kandang terhadap pertumbuhan dan hasil tiga kultivar kacang hijau (Vigna radiata L. Wilczek) di lahan pasir pantai Bugel, Kulon Progo. Vegetalika. 3(3): 78-88.

Alvernia, P., Minardi, S., \& Suntoro, S. 2017. Zeolite and organic fertilizer application to the improvement of available $\mathrm{p}$ and soybean (Glycine max L) seed yield in Alfisols. Sains Tanah Journal of Soil Science and Agroclimatology. 14(2): 83-89.

Astiko, W., Sastrahidayat, I. R., Djauhari, S., \& Muhibuddin, A. (2013). The role of indigenous mycorrhiza in combination with cattle manure in improving maize yield (Zea Mays L) on sandy loam of Northern Lombok, Eastern of Indonesia. Journal of Tropical Soils. 18(1): 53-58.

Azcon, R., Barea, J. M., \& Hayman, D. S. (1976). Utilization of rock phosphate in alkaline soils by plants inoculated with mycorrhizal fungi and phosphate-solubilizing bacteria. Soil Biology and Biochemistry. 8(2):135138.

Barus, M., R. Rogomulyo, dan S. Trisnowati 2013. Pengaruh takaran pupuk kandang terhadap pertumbuhan dan hasil wijen (Sesamum indicum L.) di lahan pasir pantai. Vegetalika $4(2): 45-54$.

BPS. 2018. Hasil Survei Pertanian Antar Sensus (SUTAS) 2018. Badan Pusat Statistik.

Bruun, E. W., Petersen, C., Strobel, B. W., \& Hauggaard-Nielsen, H. 2012. Nitrogen and carbon leaching in repacked sandy soil with added fine particulate biochar. Soil Science Society of America Journal. 76(4): 1142.

Cai, A., Xu, M., Wang, B., Zhang, W., Liang, G., Hou, E., \& Luo, Y. 2019. Manure acts as a better fertilizer for increasing crop yields than synthetic fertilizer does by improving soil fertility. Soil and Tillage Research. 189:165-175.

Caravaca, F., Alguacil, M. M., Azcón, R., Díaz, G., \& Roldán, A. 2004. Comparing the effectiveness of mycorrhizal inoculation and amendment with sugar beet, rock phosphate and Aspergillus niger to enhance field performance of the leguminous shrub Dorycnium pentaphyllum L. Applied Soil Ecology. 25 (2): 169-180.

Głąb, T., A. Żabiński, U. Sadowska, K. Gondek, M. Kopeć, M. Mierzwa-Hersztek, S. Tabor, J. Stanek-Tarkowska. 2020. Fertilization effects of compost produced from maize, sewage sludge and biochar on soil water retention and chemical properties. Soil and Tillage Research. 197(104493): 1-10.

Haliru, M., Dikko, A., Audu, M., \& Aliyu, I. 2015. Effect of cow dung on soil properties and performance of sweet potato (Ipomoea batatas L.) in Sudan Savanna, Nigeria. International Journal of Plant \& Soil Science. 5(4): 212-216.

Hasibuan, A. S. Z. 2015. Pemanfaatan bahan organik dalam perbaikan beberapa sifat tanah pasir pantai selatan Kulon Progo. Planta Tropika: Journal of Agro Science. 3(1), 31-40.

Herawati, A., Syukur, A., \& Shiddieq, D. 2011. Pengaruh takaran pupuk phonska lapis ganda terhadap distribusi vertikal dan serapan $\mathrm{N}$ oleh bibit jeruk di Lahan Pasir Pantai Bugel, Kulonprogo. Dalam Prosiding Seminar Nasional HITI X. Surakarta: Jurusan Ilmu Tanah Fakultas Pertanian UNS. hal. 220-227.

Hu, J., Lin, X., Wang, J., Dai, J., Cui, X., Chen, R., \& Zhang, J. 2009. Arbuscular mycorrhizal fungus enhances crop 
yield and P-uptake of maize (Zea mays L.): a field case study on a sandy loam soil as affected by long-term Pdeficiency fertilization. Soil Biology and Biochemistry. 41(12): 24602465.

Johnson, N. C. \& Jansa, J. 2016. Mycorrhizas: at the interface of biological, soil, and earth sciences. In Johnson, N. C et. al. (Eds). Mycorrhizal Mediation of Soil: Fertility, Structure, and Carbon Storage. Earth Sciences and Environmental Sustainability, School of Biological Sciences. Elsevier Inc.

Kasno, A., \& Sutriadi, M. T. 2012. Indonesian rock-phosphate effectivity for maize crop on Ultisols soils. AGRIVITA Journal of Agricultural Science. 34(1): 14-21.

Kertonegoro, B. D., Shiddieq, D., Sulakhudin, \& Dariah, A. 2007. Optimalisasi lahan pasir pantai Bugel Kulonprogo untuk pengembangan tanaman hortikultura dengan teknologi inovatif berkearifan lokal. Dalam Prosiding Seminar Nasional Sumberdaya Lahan dan Lingkungan Pertanian. Bogor: Balai Besar Litbang Sumberdaya Lahan Pertanian, Badan Penelitian dan Pengembangan Pertanian, Departemen Pertanian.

Kertonegoro, B. D., Siradz, S. A., Yulianta, A., \& Negara, A. K. 2010. Physico-chemical characteristics and mineralogy of coastal sandy soils occuring on different ages of dunes. In Proceeding The International Seminar on "Development of Coastal Sandy Area Towards Sustainable Agriculture. Gadjah Mada University, 13 - 14 Februari 2010.

Li, Y., Wang, S., Lu, M., Zhang, Z., Chen, M., Li, S., \& Cao, R. 2019. Rhizosphere interactions between earthworms and arbuscular mycorrhizal fungi increase nutrient availability and plant growth in the desertification soils. Soil and Tillage Research. 186:146-151.

Maryanto, J. \& Abubakar. 2010. Pengaruh konsentrasi pupuk hayati majemuk dan batuan fosfat alam terhadap serapan $\mathrm{P}$ oleh tanaman selada (Latuca sativa L.) di tanah Andisols. Agrivigor. 3(2), 110-117.

Masruroh, A., . S., \& Minardi, S. 2019. Rock phosphate, zeolite and quail manure to enhance potassium uptake and yield of soybean on Alfisols. Asian Journal of Soil Science and Plant Nutrition.5(1):1-9.

Nurhidayati, T., K.I. Purwani, dan D. Ermavitalini. 2010. Isolasi mikoriza vesikular-arbuskular pada lahan kering. Berk. Penel. Hayati Edisi Khusus. 4F:43-46.

Ortas, I., \& Ustuner, O. 2014. The effects of single species, dual species and indigenous mycorrhiza inoculation on citrus growth and nutrient uptake. European Journal of Soil Biology. 63:64-69.

Rillig, M. C. 2004. Arbuscular mycorrhizae, glomalin, and soil aggregation. Canadian Journal of Soil Science. 84(4):355-363.

Simfukwe, E. J., \& Tindwa, H. J. 2018. Rock phosphate-solubilising potential of fungal and bacterial isolates from soils surrounding panda hill and minjingu phosphate rock deposits in Tanzania. Tropical Ecology. 59(1): 109-118

Singh, P. K., Singh, M., \& Tripathi, B. N. 2013. Glomalin: An arbuscular mycorrhizal fungal soil protein. Protoplasma. 250(3): 663-669.

Sithole, N. J., \& Magwaza, L. S. 2019. Long-term changes of soil chemical characteristics and maize yield in notill conservation agriculture in a semi-arid environment of South Africa. Soil and Tillage Research. 194:1-9.

Smith, S. E., Jakobsen, I., Grønlund, M., \& Smith, F. A. 2011. Roles of arbuscular mycorrhizas in plant phosphorus nutrition: Interactions between pathways of phosphorus uptake in arbuscular mycorrhizal roots have important implications for understanding and manipulating plant phosphorus acquisition. Plant 
Physiology. 156(3):1050-1057.

Smith, S. E., \& Read, D. 2008. Mycorrhizal Symbiosis. Third Edition. Academic Press, Elsevier. Britain.

Sosa-Hernández, M. A., Leifheit, E. F., Ingraffia, R., \& Rillig, M. C. 2019. Subsoil arbuscular mycorrhizal fungi for sustainability and climate-smart agriculture: a solution right under our feet?. Frontiers in Microbiology, 10:744.

Syamsiyah, J., B. H. Sunarminto, E. Hanudin. J. Widana. 2014. Pengaruh inokulasi jamur mikoriza arbuskula terhadap glomalin, pertumbuhan dan hasil padi. Sains Tanah - Jurnal Ilmiah Ilmu Tanah dan Agroklimatologi. 11(1): 39-46.

Syamsiyah, J., Herawati, A., \& Mujiyo. 2018. The potential of arbuscular mycorrhizal fungi application on aggregrate stability in Alfisol soil. IOP Conference Series: Earth and Environmental Science. 142(2018) 012045.

Syib'li, M. A., Muhibuddin, A., \& Djauhari, S. 2013. Arbuscular mycorrhiza fungi as an indicator of soil fertility. Agrivita 35(1): 44-53.

Syukur, A., Shiddieq, D., \& Yuwono, T. 2010. Effect of coated urea with humiccalcium on transformation of nitrogen in coastal sandy soil a soil column method. Jurnal Tanah Tropika. 15(1): 25-32.

Treseder, K. K., \& Turner, K. M. 2007. Glomalin in ecosystems. Soil Science Society of America Journal. 71 (4):1257-1266.

Watts-Williams, S. J., Turney, T. W., Patti, A. F., \& Cavagnaro, T. R. 2014. Uptake of zinc and phosphorus by plants is affected by zinc fertiliser material and arbuscular mycorrhizas. Plant and Soil. 376: 165-175.

Weber, J., Karczewska, A., Drozd, J., Licznar, M., Licznar, S., Jamroz, E., \& Kocowicz, A. 2007. Agricultural and ecological aspects of a sandy soil as affected by the application of municipal solid waste composts. Soil Biology and
Biochemistry. 39(6):1294-1302.

Xie, H., Li, J., Zhang, B., Wang, L., Wang, J., He, H., \& Zhang, X. 2015. Long-term manure amendments reduced soil aggregate stability via redistribution of the glomalin-related soil protein in macroaggregates. Scientific Reports. 5: 14687. 